\title{
Effect of adding nitrate on the performance of a multistage biofilter used for anaerobic treatment of high strength wastewater
}

\author{
S. Ghaniyari-Benis ${ }^{1}$, R. Borja ${ }^{2}$, M. Bagheri ${ }^{1}$, S. Ali Monemian ${ }^{3}$, \\ V. Goodarzi ${ }^{3}$, Z. Tooyserkani ${ }^{4}$ \\ ${ }^{1}$ Department of Chemical and Petroleum Engineering, Sharif University of \\ Technology (SUT), P.O. Box: 11365-8639, Tehran, Iran. \\ ${ }^{2}$ Instituto de la Grasa (C.S.I.C.), Avda. Padre García Tejero, 4, 41012-Sevilla, \\ Spain \\ ${ }^{3}$ School of Chemical Engineering, University of Tehran, P.O. Box 11155-4563, \\ Tehran, Iran. \\ ${ }^{4}$ Department of Chemical and Biological Engineering, University of British \\ Columbia, 2360 East Mall, Vancouver, BC, Canada V6T $1 Z 3$.
}

\begin{abstract}
This laboratory research was carried out to evaluate the performance of a multistage anaerobic biofilm reactor, with six compartments and a working volume of $70 \mathrm{~L}$, for the treatment of a strong synthetic nitrogenous and high-strength wastewater at an operational temperature of $26^{\circ} \mathrm{C} \pm 0.5^{\circ} \mathrm{C}$. Initially, the performance of the reactor was studied when subjected to an increase in the hydraulic retention time (HRT) at a constant influent COD concentration of $10000 \mathrm{mg} / \mathrm{L}$. Five different HRTs were studied: 0.25, 0.67, 1, 3 and 5 days, which were equivalent to $6,16,24,72$ and 120 hours, respectively . By increasing the HRTs from $6 \mathrm{~h}$ to 1 day, COD and BOD removal efficiencies were increased from $63 \%$ to $84 \%$ and from $66 \%$ to $87 \%$, respectively. Moreover, at an HRT of 3 days, COD and BOD removal efficiencies were equal, reaching $93 \%$. In the second phase of the research, the effect of adding nitrate with a concentration of $3000 \mathrm{mg} / \mathrm{L}$ at an influent organic loading rate of $10 \mathrm{~g} \mathrm{COD} / \mathrm{L}$-day was researched on the reactor performance and the amount of biogas produced. Denitrification took place almost solely in the first three compartments of the reactor, with efficiencies of $85 \%, 95 \%$ and $98 \%$, respectively. The nitrite produced was only detected in the first and second compartments at concentrations of $138 \mathrm{mg} / \mathrm{L}$ and $24 \mathrm{mg} / \mathrm{L}$, respectively. In addition, no accumulation of nitrite was detected in the reactor. Furthermore, the denitrification caused an increase in the total volume of produced biogas from $102 \mathrm{~L} / \mathrm{d}$ to $178 \mathrm{~L} / \mathrm{d}$.
\end{abstract}

Keywords: Multistage anaerobic filter; Denitrification; Biogas; COD and BOD removal; High organic content wastewater 
"Corresponding author: R. Borja; Tel: +34 95 4689654; fax: +34 95 4691262;

E-mail: rborja@cica.es

\section{Introduction}

The anaerobic treatment of industrial effluents has a number of advantages, such as low energy consumption, low excess sludge production, the elimination of odors and methane production as an energy source [1]. The biological process of anaerobic digestion is governed significantly by the conditions under which it is run such as alkalinity, nutrient content, loading rate, toxicity of constituents, $\mathrm{pH}$ and temperature [2]. Anaerobic treatment can be improved with the use of biomass retention by the immobilization of anaerobic microorganisms [3]. Nowadays, most of the attention has been drawn to the development of high-rate anaerobic reactors for the treatment of effluents leading to the conversion of organic matter into biogas [4]. Anaerobic treatment of organic-based wastewater is the most common process for biogas production and the reduction of organic matter existing in the influent and it has been used in mesophilic and thermophilic conditions [5].

Fixed film reactors are considered to be effective in the corresponding suspended growth systems [6]. A biofilm reactor can be described as a digester with three phases of liquid, gas and biofilm. Biofilm is the complicated microbial population in which several physical, chemical and biological processes occur simultaneously [7]. Immobilization of the biomass on the support media allows for a more stable operation by improving the retention time of microorganisms and enabling the reactor to cope with a greater concentration of biomass [8]. The multistage biofilm reactor is a combination of the anaerobic baffled reactor (ABR) and upflow anaerobic fixed-bed (UAFB) treatment systems, which include the advantages of baffled reactor systems and anaerobic filters. Their properties are: better resilience to hydraulic and organic 
shock loadings, longer biomass retention times, lower sludge yields, and the ability to partially separate between the various phases of anaerobic catabolism [9]. Fixed film biofilters are widely used for the removal of organic matter and nitrogen by the twostep biological processes of nitrification-denitrification [10]. Biological denitrification demonstrates an effective bioprocess to remove nitrate and nitrite, which is carried out by denitrifiers such as paracoccus denitrificants, requiring an organic carbon source as an electron donor and energy source [11-13]. Nitrates and nitrites in water supplies have led to cases of infant methaemoglobinaemia, mutation of DNA and gastric cancer. They can also contribute to eutrophication of water bodies [10, 14-16]. The most important parameters with an important influence on the denitrification process are the nitrate content, $\mathrm{g} \mathrm{COD} / \mathrm{g} \mathrm{N}-\mathrm{NO}_{3}$ ratio, type and concentration of carbon source and the $\mathrm{pH}[17,18]$. It is recommended that for an effective denitrification the ratios of $\mathrm{g} \mathrm{BOD}_{5} / \mathrm{g} \mathrm{N}^{-\mathrm{NO}_{3}}$ and $\mathrm{g} \mathrm{COD} / \mathrm{g} \mathrm{N}^{-\mathrm{NO}_{3}}$ should be 4 and 3.71, respectively. Other research showed that the proper ratio of theoretical $\mathrm{C} / \mathrm{N}$ is $3.5-4.5 \mathrm{~g} \mathrm{COD} / \mathrm{g} \mathrm{N}-\mathrm{NO}_{3}$. In systems with pre-denitrification and post-denitrification, it has been shown that $\mathrm{C} / \mathrm{N}$ ratio of 6-11 g COD/g N-NO $\mathrm{g}_{3}$ and 3-4 $\mathrm{g} \mathrm{COD}_{\mathrm{f}}$ (filtered $\mathrm{COD}$ )/g N-NO 3 were needed, respectively [19].

The aim of this study was to evaluate the performance and practicability of a multistage anaerobic biofilm reactor composed of six sequential compartments treating high-strength synthetic wastewater in both states with absence and presence of nitrate. The results of experiments concerning nitrate addition on COD and BOD removals, VFAs, ammonia, biogas production and nitrate removal were researched under anaerobic condition. In the first phase of the experiments, the effect of increasing HRT on the reactor performance and the efficiency of the process are discussed. In the second phase, the influence of the addition of nitrogen as an 
alternative electron acceptor for nitrogen removal in the reactor is explored under a high nitrate concentration.

\section{Materials and methods}

\subsection{Laboratory-scale experimental set-up}

A scheme of the experimental set-up, including a flow diagram and reactor details are shown in Figure 1. The multistage biofilm reactor was composed of six discrete compartments with a total working volume of $70 \mathrm{~L}$. The six compartments were made from "Plexiglas" with identical geometric characteristics, a total volume of $12 \mathrm{~L}$ and a gas accumulation space of $0.75 \mathrm{~L}$ for each one. The baffles inside the reactor were used to direct the flow of wastewater in an upflow mode through a series of compartments where each one formed a packed bed using Raschig Rings as a media to support the biofilm formation. The main characteristics of this Raschig Ring packing were: material, metal; nominal size, $13 \mathrm{~mm}$; height, $25 \mathrm{~mm}$; wall thickness, $0.8 \mathrm{~mm}$; surface area, $420 \mathrm{~m}^{2} / \mathrm{m}^{3}$; and $85 \%$ porosity. The porosity of the beds was $81 \%$ and the fixed beds were placed up to a height of $40 \mathrm{~cm}$ from the bottom of the reactor. The beds maintained $73 \%$ porosity after cell immobilization.

The reactor was covered with a water jacket which kept the operational temperature at $26^{\circ} \mathrm{C} \pm 0.5^{\circ} \mathrm{C}$, and effluent wastewater from the sixth compartment was discharged. The six compartments operated only in an anaerobic regime. Sampling taps provided on the wall of each compartment allowed extraction of samples for analysis in various chambers of the biofilm reactor.

\subsection{Synthetic wastewater}


The reactor was fed with synthetic wastewater containing molasses as a carbon source. The characteristics of the said molasses used were: $\mathrm{pH}, 7.4$; COD, $1029 \mathrm{mg} / \mathrm{L}$; BOD $_{5}: 325 \mathrm{mg} / \mathrm{L}$; Kjeldahl nitrogen, $18.3 \mathrm{mg} / \mathrm{L}$; total phosphate, $0 \mathrm{mg} / \mathrm{L} ; \mathrm{Fe}^{2+}, 0$ $\mathrm{mg} / \mathrm{L} ; \mathrm{Ca}^{2+}, 59.2 \mathrm{mg} / \mathrm{L} ; \mathrm{K}^{+}, 3.2 \mathrm{mg} / \mathrm{L}$; alkalinity, $207 \mathrm{mg} / \mathrm{L}$. During the start-up period, ammonium phosphate and urea were used as sources of phosphorus and nitrogen, respectively. Micronutrients and trace metals with the following composition were also added during the start-up period: $\mathrm{CoCl}_{2} \cdot 6 \mathrm{H}_{2} \mathrm{O}, 0.25 \mathrm{mg} / \mathrm{L}$; $\mathrm{H}_{3} \mathrm{BO}_{3}, 0.05 \mathrm{mg} / \mathrm{L} ; \mathrm{FeSO}_{4} \cdot 7 \mathrm{H}_{2} \mathrm{O}, 0.5 \mathrm{mg} / \mathrm{L} ; \mathrm{MnCl}_{2} \cdot 4 \mathrm{H}_{2} \mathrm{O}, 0.5 \mathrm{mg} / \mathrm{L} ; \mathrm{ZnCl}_{2}, 0.05$ $\mathrm{mg} / \mathrm{L} ; \mathrm{CuCl}_{2}, 0.15 \mathrm{mg} / \mathrm{L} ; \mathrm{Na}_{2} \mathrm{MoO}_{4} \cdot 2 \mathrm{H}_{2} \mathrm{O}, 0.01 \mathrm{mg} / \mathrm{L} ; \mathrm{NiSO}_{4} \cdot \mathrm{H}_{2} \mathrm{O}, 0.02 \mathrm{mg} / \mathrm{L}$; $\mathrm{Na}_{2} \mathrm{SeO}_{3}, 0.01 \mathrm{mg} / \mathrm{L} ; \mathrm{AlCl}_{3}, 6 \mathrm{H}_{2} \mathrm{O}, 0.05 \mathrm{mg} / \mathrm{L} ; \mathrm{MgSO}_{4} \cdot 7 \mathrm{H}_{2} \mathrm{O}, 0.3 \mathrm{mg} / \mathrm{L}$. During the start-up period, the COD:N:P ratio was 100:5:1. When a steady-state condition was achieved, the COD:N:P ratio was changed to $350: 5: 1$. In order to neutralize any VFA accumulation and prevent acid zone forming in the reactor, sodium bicarbonate was used as an alkalinity supplement. Given the appropriate $\mathrm{pH}$ of the influent used as feed (7.4) the volume of the sodium bicarbonate solution added was very small in all cases.

\subsection{Seeding and experimental procedure}

The microorganisms used as inoculum in the reactor came from the sludge of a lab-scale ANAMMOX-AFBR system which had been treating strong nitrogenous wastewater for the past three years. The reactor was initially seeded with $27 \mathrm{~L}$ of anaerobic sludge. The basic characteristics of the inoculum used were: $1857 \mathrm{mg} / \mathrm{L}$ of total nitrogen, $967 \mathrm{mg} / \mathrm{L}$ of ammonia nitrogen, a total acidity of $367 \mathrm{mg}$ acetic acid/L; $96 \mathrm{~g} / \mathrm{L}$ of total solid content, $40 \mathrm{~g} / \mathrm{L}$ of volatile solid content, $1.898 \mathrm{~g} \mathrm{CaCO}_{3} / \mathrm{L}$ of bicarbonate alkalinity and a $\mathrm{pH}$ of 6.8 . 
At the beginning of the experiments, for effective biofilm formation on the support media, the reactor was initially started by increasing the organic loading rate from 0.5 to $2.5 \mathrm{~g} \mathrm{COD} / \mathrm{L}$ per day in a fed-batch mode. After a batch feeding period of two months, an influent molasses-based wastewater was used as a second feeding step in continuous mode at a constant organic loading rate of $4 \mathrm{~g} \mathrm{COD} / \mathrm{L} \cdot \mathrm{d}$ for another period of two months.

The reactor was operated until a steady-state performance was reached. The steady-state experiments were conducted in two consecutive phases. In the first phase of the experiments, the bioreactor was subjected to increasing HRTs and the performance of the system was evaluated. Five HRTs $(0.25,0.67,1,3$ and 5 days, equivalent to $6,16,24,72$ and 120 hours, respectively) were studied at a constant influent COD concentration of $10000 \mathrm{mg} / \mathrm{L}$. In the second phase, biological denitrification was assessed by studying nitrate reduction and its influence on the reactor performance and biogas production at a constant influent organic loading rate (OLR) of $10 \mathrm{~g} \mathrm{COD} / \mathrm{L} \cdot \mathrm{d}$ and nitrate concentration of $3000 \mathrm{mg} \mathrm{N}-\mathrm{NO}_{3} / \mathrm{L}$.

\subsection{Analytical Methods}

The COD concentration was measured by using a semi-micro method [20]. Total VFA concentrations in the samples were analyzed using a titrimetric method [21]. Nitrate and nitrite were determined with an ion chromatography analyzer (ALLTECH 1000, ERIS ${ }^{\mathrm{TM}}$, USA). Ammonia-nitrogen was detected by the $4500-\mathrm{NH}_{3} \mathrm{D}$ method, with a NH500/2 WTW ion selective electrode and WTW pH 320m. Electrodes were calibrated according to the manufacturer's procedures. BOD was measured according to standard methods [22]. Daily liquid samples were withdrawn and centrifuged at $13000 \mathrm{rpm}$ for $8 \mathrm{~min}$ until a clear supernatant was obtained. 
The composition of the biogas $\left(\mathrm{CH}_{4}, \mathrm{CO}_{2}\right.$ and $\left.\mathrm{N}_{2}\right)$ was analyzed using a gas chromatograph (Varian 3400, Walnut Creek, USA) equipped with a Haysep Q (mesh of $80-100 \mu \mathrm{m}$ ) column, a molecular sieve column and a thermal conductivity detector. The temperatures of the injector and detector were kept at $100^{\circ} \mathrm{C}$ and $120^{\circ} \mathrm{C}$, respectively. Helium was used as the carrier gas at a flow-rate of $12 \mathrm{~mL} / \mathrm{min}$. The volume of biogas produced was monitored by a gas counter (Milligascounter ${ }^{\mathrm{TM}}$ ) and recorded on a computer. $\mathrm{pH}$ was measured using a pH meter (Crison GLP 22).

The steady-state values of operational parameters were taken as the average of seven successive measurements for those parameters when the deviations between the values were less than $3 \%$ in all cases.

\section{Results and discussion}

\subsection{Phase I: Effect of increasing HRT on the reactor performance}

This phase of the research studies the effect of increasing HRT on the system performance over 185 days. Figure 2 shows the results related to the variation of COD and BOD concentrations throughout the system for the different HRTs studied and an influent COD concentration of $10000 \mathrm{mg} / \mathrm{L}$. As can be seen, the COD and BOD removal efficiencies were increased by raising the retention time from $6 \mathrm{~h}$ to 5 days.

At an HRT of $6 \mathrm{~h}$, the total COD and BOD removal efficiencies reached $63 \%$ and $66 \%$ respectively, and the first four reactor chambers played an effective role during the organic matter reduction process. The effluent COD concentration from the first four stages reached 7288, 5329, 4425 and $4028 \mathrm{mg} / \mathrm{L}$ and for BOD reached 3807, 2915, 2553 and $2023 \mathrm{mg} / \mathrm{L}$, respectively. At an HRT of $16 \mathrm{~h}$, the outlet COD and BOD concentrations from the first chamber reached 4875 and $2611 \mathrm{mg} / \mathrm{L}$ 
respectively. Therefore, almost half of the existing organic contaminants in the synthetic wastewater was removed in the first compartment, while the whole COD and BOD removal efficiencies achieved at this HRT were $73 \%$ and $75 \%$ respectively. At an HRT of 1 day, COD and BOD removal efficiencies in the first compartment were $62 \%$ and $66 \%$ respectively, which indicates that the role of the first compartment becomes more important, especially for reducing the organic matter from a wastewater by increasing the HRT. In this way, the final effluent COD and BOD concentrations from the reactor reached 1587 and $707 \mathrm{mg} / \mathrm{L}$, respectively.

For HRTs of 3 and 5 days, the results were very similar. Therefore, the COD and BOD removal efficiencies were very similar for these two retention times, reaching 93\%. The results show that an HRT of 3 days is an optimum retention time for this system.

At an HRT of 3 days, the exhaust COD concentrations from the fifth and sixth compartments were equal to 888 and $699 \mathrm{mg} / \mathrm{L}$, while at an HRT of 5 days they were 688 and $595 \mathrm{mg} / \mathrm{L}$. The result showed that the role of the first compartment became more significant with increasing HRT, and at an HRT of 5 days a COD removal of $74 \%$ was almost achieved in the first compartment.

A previous study using a multistage (three compartments) anaerobic biofilm for treating synthetic low-strength wastewater (COD: $3000 \mathrm{mg} / \mathrm{L})$ revealed an increase in COD removal efficiency from $84.9 \%$ to $91.6 \%$ when HRT rose from 8 h to $24 \mathrm{~h}$ [23]. The relatively poor performance observed at a HRT of $8 \mathrm{~h}$ was attributed principally to the instability created by the sudden doubling of the influent loading rate. COD removal efficiency also increased from $69 \%$ to $79 \%$ when the HRT rose from $18 \mathrm{~h}$ to $48 \mathrm{~h}$ in a carried anaerobic baffled reactor (ABR) treating sewage at $28^{\circ} \mathrm{C} \pm 1^{\circ} \mathrm{C}$ [24]. This reactor was rectangular and contained six chambers of equal volume, the 
effective reactor volume being $17 \mathrm{~L}$. The six upcomer regions of this reactor were filled with hollow-sphere carriers made of bamboo (approx. $15 \mathrm{~cm}$ in diameter) in settled form. Another modified ABR consisting of three 3.6 L chambers (the first one was a UASB without a gas-solid-liquid separator, the second one was a down-flow fixed-film reactor with plastic media, while the third one was a hybrid UASB-AF with plastic Pall Ring media) was used for treating pre-settled municipal wastewater at ambient temperature $\left(18^{\circ} \mathrm{C}-28^{\circ} \mathrm{C}\right)$ [25]. In this study, COD removal increased from $52.3 \%$ to $67.8 \%$ when the HRT increased from $2 \mathrm{~h}$ to $4 \mathrm{~h}$.

In relation to the variations profile of VFA concentration (Figure 3A), it was observed that for all HRTs studied, the VFA values dropped from the first to the sixth compartments. At an early stage in the process and since the growth rate of acetogens is higher and the methanogens have not grown enough, the VFA values are high. However, with the passing of time and an increase in the growth of methanogens, the VFA values dropped with increasing HRT, and the VFA values decreased in all chambers.

At HRTs of $6 \mathrm{~h}, 16 \mathrm{~h}$ and 1 day, the VFA values decreased more sharply, and, therefore, more quickly from the second to the fourth compartments, which revealed a stronger presence of methanogens in the second and third chambers. The outlet VFA values from the reactor were almost equal at HRTs of 3 and 5 days, and this equaled the removal efficiency at these two HRTs. High VFA values were found at an HRT of $6 \mathrm{~h}$, which shows that by reducing the contact time between wastewater and biomass, there was not enough time to transform VFAs to end products and the outflow COD was commonly constituted by volatile fatty acids.

VFA concentrations in effluents of a multistage anaerobic migrating blanket reactor (AMBR) increased from 25 to $182 \mathrm{mg} / \mathrm{L}$ as the HRT decreased from 10.3 days 
to 1 day treating synthetic wastewater containing glucose as a carbon source [26]. This AMBR reactor consisted of a rectangular tank with an active volume of $13.5 \mathrm{~L}$, which was divided into three compartments, which were mixed equally every 15 minutes at $60 \mathrm{rpm}$ to ensure gentle mixing.

An increase in $\mathrm{pH}$ values was observed from the first to sixth compartment (Figure 3B). This rise in $\mathrm{pH}$ in reactors like the $\mathrm{ABR}$ system is caused by phase separation (acidogenesis and methanogenesis). $\mathrm{pH}$ values in each chamber had an increasing trend, which could also be caused by the production of compounds that increase the alkalinity by substrate degradation.

Microscopic observations carried out in an anaerobic rotating biological contactor (AnRBC) consisted of four compartments, each one containing fifteen 12 $\mathrm{cm}$ diameter acrylic plastic disks, showing that the acetogenic microorganisms were predominant in the first two compartments, while the methanogenic microorganisms were predominant in the last two [27]. The volatile fatty acid profile observed in an eight chambered ABR treating complex wastewater made of cellulose and sucrose (40:60) also demonstrated that hydrolysis and acidogenesis are the main biochemical activities in the first few compartments [28].

\subsection{Phase II: Influence of nitrate addition on the reactor performance}

The second phase of the research was carried out with the addition of nitrate at a concentration of $3000 \mathrm{mg} / \mathrm{L}$ and a constant organic loading of $10 \mathrm{~g} \mathrm{COD} / \mathrm{L} \cdot \mathrm{d}$. For two weeks, after adding nitrate, the nitrogen concentration at gas phase showed no increase, caused by the time needed for the initial growth of the denitrifiers. Figure 4 shows the variation trend of the nitrate and nitrite produced. As can be seen in Figure 4, the main part of the existing nitrate at feed was removed in the first compartment, 
so that the exhaust nitrate concentration from the first three chambers reached 455 , 147 and $54 \mathrm{mg} / \mathrm{L}$ respectively. Therefore, virtually all of nitrate present at feed was removed, the denitrification efficiencies in the first, second and third chambers being $85 \%, 95 \%$ and $98 \%$, respectively.

The produced nitrite concentration measurement inside the reactor showed that only traces of nitrite were found in the first and second chambers, with nitrite concentrations of $138 \mathrm{mg} / \mathrm{L}$ and $24 \mathrm{mg} / \mathrm{L}$ in the first and second chambers respectively. In the other chambers, the maximum nitrite concentration measured was equal to $4 \mathrm{mg} / \mathrm{L}$. These small quantities indicate a lack of nitrite accumulation inside the reactor.

Figure 5 illustrates the denitrification effect on the organic matter removal and VFA concentrations. The effluent COD and BOD concentrations from the reactor reached $750 \mathrm{mg} / \mathrm{L}$ and $211 \mathrm{mg} / \mathrm{L}$, which is equivalent to COD and BOD removal efficiencies of $92 \%$ and $96 \%$, respectively. In comparison with the previous phase studied (with absence of nitrate), denitrification caused an increase in COD, BOD and VFA removals, so that COD and BOD removal efficiencies increased at almost the same rate - about $10 \%$. In this phase, the denitrification process at the front compartments of the reactor increased the organic matter removal. This increase in the removal efficiency is due to the oxidation of some COD feed for the required energy and carbon source supply for nitrate reduction.

A previous study reported that denitrification occurred almost exclusively in the front two compartments of an anaerobic baffled reactor (ABR) with eight compartments, with rates of 0.335 (82\% reduction) and $0.085 \mathrm{~g} \mathrm{NO}_{3} / \mathrm{g}$ VSS day $(96 \%$ reduction) in compartments 1 and 2, respectively [29]. Denitrification had several positive effects on overall reactor performance, and this was due to the following 
factors: the use of an oxidisable electron donor in the form of the COD feed and increased system $\mathrm{pH}$ at the reactor inlet, thus improving environmental conditions [29].

The denitrification process was carried out by using nitrate by facultative denitrificants in the absence of free molecular oxygen to degrade exogenous carbon and obtain energy for cellular activity and synthesis. During anaerobic respiration, nitrate and nitrite are reduced through several pathways. The overall biochemical reaction for denitrification with a carbon source [30] can be expressed by the following theoretical equation:

$$
24 \mathrm{NO}_{3}{ }^{-}+5 \mathrm{C}_{6} \mathrm{H}_{12} \mathrm{O}_{6} \Rightarrow 12 \mathrm{~N}_{2}+30 \mathrm{CO}_{2}+18 \mathrm{H}_{2} \mathrm{O}+24 \mathrm{OH}^{-}
$$

From stoichiometry of equation (1), it is determined that for performing denitrification, COD consumption and nitrate ratio must coincide with $\mathrm{COD} / \mathrm{NO}_{3}=0.605$ mass fraction. As a result of this equation, COD removal efficiency increases in the presence of nitrate. $\mathrm{pH}$ variations during nitrate reduction ranged between $6.5-8.1$ in the present study. Therefore, these values by comparison with those reported in the previous experiment (without nitrate addition), the average $\mathrm{pH}$ was increased by about 0.27 .

Although an increase in $\mathrm{pH}$ should cause an increase in the production of methane, the inhibitory effects induced for the intermediate compounds derived from denitrification caused the methane production to stop and decrease [30]. This same behaviour was previously observed in the anaerobic treatment of synthetic substrates with a high nitrate concentration, resulting in the accumulation of undesirable intermediates such as $\mathrm{N}_{2} \mathrm{O}$ [31]. Therefore, the addition of nitrate to the process has three momentous and contrary effects on biofilter performance [32]:

1) Quick reduction of $\mathrm{NO}_{3}{ }^{-}$by facultative anaerobes through anaerobic respiration. 
2) Foaming formation as a consequence of the rising gaseous nitrogen.

3) Increasing redox potential of the sludge system. An increase in redox potential hampers the methanogeneous activity of the microorganisms that transform VFAs to methane. The interaction between denitrification and methanogenesis, with methanol functioning as an electron donor, has been examined previously through the usage of a mixed culture system of denitrifying sludge and methanogenic sludge in an anaerobic reactor [33]. Competition for methanol between these two kinds of sludges could not be observed, whereas methanogenesis was suppressed as long as nitrate was made available in the mixed system. Adding nitrate also raised the redox potential of the system [33].

The production yield of the different components of the biogas with or without nitrate is presented in Figure 6.

During the nitrate reduction process, the $\mathrm{CO}_{2}$ content was increased, so that the produced $\mathrm{CO}_{2}$ volume was increased from $38.2 \mathrm{~L} / \mathrm{d}$ with a lack of nitrate to $75.1 \mathrm{~L} / \mathrm{d}$ during denitrification. With added nitrate, the total amount of the biogas production increased from $102 \mathrm{~L} / \mathrm{d}$ to $178 \mathrm{~L} / \mathrm{d}$, which shows about a $74 \%$ rise. The maximum biogas production was observed in the third compartment for both studies carried out (with and without added nitrate).

However, the decrease in methane production by adding nitrate can be attributed to the inhibition effects caused by some components generated during the denitrification process $\left(\mathrm{H}_{2}\right)$ and by the accumulation of denitrification intermediates $\left(\mathrm{N}_{2} \mathrm{O}, \mathrm{NO}\right.$ and $\left.\mathrm{NO}_{2}\right)[34,35]$. As no accumulation of nitrite was observed throughout the process and all of the nitrite produced was transformed, it can therefore be considered that the inhibition effect on the methane production is caused by the presence of $\mathrm{N}_{2} \mathrm{O}$ and $\mathrm{NO}$ at gas phase. During denitrification, the methane production 
decreased from $57 \mathrm{~L} / \mathrm{d}$ to $39 \mathrm{~L} / \mathrm{d}$, which supposed a $33 \%$ reduction in the amount of methane produced per day. Moreover, the methane percentage in the biogas decreased from $56 \%$ (with absence of nitrate) to $21 \%$ during nitrate reduction.

Methane production was also stopped as soon as denitrification started in the anaerobic digestion of an industrial sulfate rich wastewater using batch cultures [11]. Concurrently, an increase in the redox potential and transient nitrite production was also observed in this study [11].

Figure 6 also shows that only in the first compartment did denitrification cause an increase in the methane production, which can come about by a larger transformation of hydrogen to methane [36] and by the dissimilatory nitrate reduction to ammonium according to the equation (2):

$$
\mathrm{NO}_{3}{ }^{-}+4 \mathrm{H}_{2}+2 \mathrm{H}^{+} \Rightarrow \mathrm{NH}_{4}^{+}+3 \mathrm{H}_{2} \mathrm{O}
$$

A high hydrogen demand during dissimilatory nitrate reduction to ammonium, improving environmental conditions for syntrophic bacteria was observed in the front two compartments of an eight compartment ABR treating a synthetic sucrose/protein wastewater with a COD content of $4000 \mathrm{mg} / \mathrm{L}$ [29].

Table 1 shows the concentrations of ammonium produced in the reactor for conditions of nitrate absence and presence (denitrification). Production of ammonium from nitrate is an ordinary reaction in anaerobic conditions as was demonstrated in equation (2) [37]. As can be seen in Table 1, before adding nitrate the concentration of ammonium in the reactor effluent reached $349 \mathrm{mg} / \mathrm{L}$, while during the denitrification reached a maximum content of $824 \mathrm{mg} / \mathrm{L}$. Other previous reported works have demonstrated that anaerobic digestion can be inhibited by ammonium concentrations in the range of $1500-3000 \mathrm{mg} / \mathrm{L}$ at $\mathrm{pH}$ values above 7.4 and by ammonium concentrations above $3000 \mathrm{mg} / \mathrm{L}$, regardless of the $\mathrm{pH}$ [38]. In the present 
study, the maximum concentration of ammonium observed was $824 \mathrm{mg} / \mathrm{L}$, which, therefore, had no negative effect on the reactor performance.

\section{Conclusions}

The reactor performance of an anaerobic multistage biofilter treating synthetic high strength wastewater was studied in two different phases. In the first phase, by increasing HRT from $0.25 \mathrm{~d}(6 \mathrm{~h})$ to $5 \mathrm{~d}$ the percentage of COD removal increased from $63 \%$ to $93 \%$. The results obtained for this system showed that an HRT of $3 \mathrm{~d}$ is the optimum HRT for treatment process. Generally, the first compartment of the reactor was the most important one during the purification process.

In the second phase of the research, the influence of nitrate addition at a concentration of $3000 \mathrm{mg} / \mathrm{L}$ on the reactor performance was studied. Denitrification occurred in the first three compartments of the reactor, with efficiencies of $85 \%, 95 \%$ and $98 \%$, respectively. Denitrification increased the percentage of organic matter removal by about $10 \%$ due to the oxidation of some COD feed for the required energy and carbon source supply for nitrate reduction.

The comparison of biogas production between the two experimental phases showed that the amount of the biogas increased from $102 \mathrm{~L} / \mathrm{d}$ to $178 \mathrm{~L} / \mathrm{d}$ when nitrate addition took place, which represented an increase of about $74 \%$. The volume of $\mathrm{CO}_{2}$ produced also increased from $38.2 \mathrm{~L} / \mathrm{d}$ without nitrate to $75.1 \mathrm{~L} / \mathrm{d}$ after nitrate was added. After nitrate addition, the content of methane in the biogas was decreased by about $35 \%$ and methane production decreased from $57 \mathrm{~L} / \mathrm{d}$ to $39 \mathrm{~L} / \mathrm{d}$. 


\section{Acknowledgements}

The authors gratefully acknowledge the financial support of the Water Research Center of Greentech (Co. Ltd), Shiraz and the R\&D center of Anshan Corporation. The authors also thank Dr. Daryoush Mehrparast and Dr. Anahita Parsnejad for their help.

\section{References}

[1] J.A. Siles, M.A. Martín, A. Chica, R. Borja, Kinetic modeling of the anaerobic digestion of wastewater derived from the pressing of orange rind produced in orange juice manufacturing, Chem. Eng. J. 140 (2008) 145-156.

[2] O. Reyes, E. Sanchez, N. Rovirosa, R. Borja, M. Cruz, M.F. Colmenarejo, R. Escobedo, M. Ruiz, X. Rodriguez, O. Correa, Low-strength wastewater treatment by a multistage anaerobic filter packed with waste tyre rubber, Bioresour. Technol. 70 (1999) 55-60.

[3] J.S. Gonzalez, A. Rivera, R. Borja, E. Sanchez, Influence of organic volumetric loading rate, nutrient balance and alkalinity: COD ratio on the anaerobic sludge granulation of an UASB reactor treating sugar cane molasses, Int. Biodeter. Biodegr. 41 (1998) 127-131.

[4] K.V. Rajeshwari, M. Balakrishnan, A. Kansal, L. Kusum, V.V.N. Kishore, Stateof-the-art of anaerobic digestion technology for industrial wastewater treatment, Renew. Sustain. Energy Rev. 4 (2000) 135-156.

[5] R. Borja, E. Gonzalez, F. Raposo, F. Millan, A. Martin, Kinetic analysis of the psychrophilic anaerobic digestion of wastewater derived from the production of 
proteins from extracted sunflower flour, J. Agric. Food Chem. 50 (2002) 46284633.

[6] S. Venkata Mohan, V. Lalit Babu, Y. Vijaya Bhaskar, P.N. Sarma, Influence of recirculation on the performance of anaerobic sequencing batch biofilm reactor (AnSBBR) treating hypersaline composite chemical wastewater, Bioresour. Technol. 98 (2006) 1373-1379.

[7] J. Perez, C. Picioreanu, M. Van Loosdrecht, Modeling biofilm and floc diffusion processes based on analytical solution of reaction-diffusion equations, Water Res. 39 (2004) 1311-1323.

[8] A.P. Miqueleto, J.A.D. Rodrigues, S.M. Ratusznei, E. Foresti, M. Zaiat, Treatment of easily degradable wastewater in a stirred anaerobic sequencing batch biofilm reactor, Water Res. 39 (2005) 2376-2384.

[9] W.P. Barber, D.C. Stuckey, The use of the anaerobic baffled reactor (ABR) for wastewater treatment: a review, Water Res. 33, 7 (1999) 1559-1578.

[10] J.M. Galvez, M.A. Gomez, E. Hontoria, J. Gonzalez-Lopez, Influence of hydraulic loading and air flow-rate on urban wastewater nitrogen removal with a submerged fixed-film reactor, J. Hazard. Mater. B101 (2003) 219-229.

[11] G. Percheron, N. Bernet, R. Moletta, Interactions between methanogenic and nitrate reducing bacteria during the anaerobic digestion of an industrial sulfate rich wastewater, FEMS Microbiol. Ecol. 29 (1999) 341-350.

[12] F.J. Cervantes, D.A. De la Rosa, J. Gomez, Nitrogen removal from wastewaters at low $\mathrm{C} / \mathrm{N}$ ratios with ammonium and acetate as electron donors, Bioresour. Technol. 79 (2001) 165-170. 
[13] L.W. Xiao, M. Rodgers, J. Mulqeen, Organic carbon and nitrogen removal from a strong wastewater using a denitrifying suspended growth reactor and a horizontal-flow biofilm reactor, Bioresour. Technol. 98 (2007) 739-744.

[14] M. Rodgers, X.M. Zhan, Biological nitrogen removal using a vertically moving biofilm system, Bioresour. Technol. 93 (2003) 313-319.

[15] T. Sumino, K. Isaka, H. Ikuta, Y. Saiki, T. Yokota, Nitrogen removal from wastewater using simultaneous nitrate reduction and anaerobic ammonium oxidation in single reactor, J. Biosci. Bioeng. 102 (2006) 346-351.

[16] J. Reyes-Avila, E. Razo-Flores, J. Gomez, Simultaneous biological removal of nitrogen, carbon and sulfur by denitrification, Water Res. 38 (2004) 3313-3321.

[17] I. Anderson, J. Levine, Relative rates of nitric oxide and nitrous oxide production by nitrifier, denitrifiers and nitrate respires, Appl. Environ. Microbiol. 51 (1986) 938-945.

[18] D.T. Sponza, H. Atalay, Influence of nitrate and COD on phosphorus, nitrogen and dinitrotoluene (DNT) removals under batch anaerobic and anoxic conditions, Anaerobe 10 (2004) 287-293.

[19] M. Komorowska-Kaufman, H. Majcherek, E. Klaczynski, Factors affecting the biological nitrogen removal from wastewater, Process Biochem. 41 (2006) 10151021.

[20] M. Soto, M.C. Veiga, R. Mendez, J.M. Lema, Semi-micro COD determination method for high salinity wastewater, Environ. Technol. Lett. 10 (1989) 541-548.

[21] G.K. Anderson, G. Yang, Determination of bicarbonate and total volatile acid concentration in anaerobic digesters using a simple titration, Water Environ. Res. 64 (1992) 53-59. 
[22] Standard Methods for the Examination of Water and Wastewater, 20th ed., APHA, AWWA, WPCF, Washington, DC, 1998.

[23] S. Ghaniyari-Benis, R. Borja, S. Ali Monemian, V. Goodarzi, Anaerobic treatment of synthetic medium-strength wastewater using a multistage biofilm reactor, Bioresour. Technol., 100 (2009) 1740-1745.

[24] H. Feng, L. Hu, Q. Mahmood, C. Qiu, C. Fang, D. Shen, Anaerobic domestic wastewater treatment with bamboo carrier anaerobic baffled reactor, Int. Biodeter. Biodegr. 62 (2008) 232-238.

[25] H. Yu, G.K. Anderson, Performance of a combined anaerobic reactor for municipal wastewater treatment at ambient temperature, Resour. Conserv. Recy. 17 (1996) 259-271.

[26] O.S. Kuscu, D.T. Sponza, Kinetics of para-nitrophenol and chemical oxygen demand removal from synthetic wastewater in an anaerobic migrating blanket reactor, J. Hazard. Mater. 161 (2009) 787-799.

[27] A.C. Yeh, C. Lu, M.R. Lin, Performance of an anaerobic rotating biological contactor: Effects of flow-rate and influent organic strength. Water Res. 31 (1997) 1251-1260.

[28] G.V.T. Gopala-Krishna, P. Kumar, P. Kumar, Complex wastewater treatment using an anaerobic baffled reactor, Environ. Progress 26 (2007) 391-397.

[29] W.P. Barber, D.C. Stuckey, Nitrogen removal in a modified anaerobic baffled reactor (ABR): 1, Denitrification, Water Res. 34 (2000) 2413-2422.

[30] R. Roy, R. Conrad, Effect of methanogenic precursors (acetate, hydrogen, propionate) on the suppression of methane production by nitrate in anoxic rice field soil, FEMS Microbiol. Ecol. 28 (1999) 49-61. 
[31] F. Cervantes, O. Monroy, J. Gómez, Accumulation of intermediates in a denitrifying process at different copper and high nitrate concentrations, Biotechnol. Letters, 20 (1998) 959-961.

[32] M.H. Gerardi, Nitrification and Denitrification in the Activated Sludge Process, John Wiley \& Sons, Inc., Publication, 2002

[33] K.C. Chen, Y.F. Lin, The relationship between denitrifying bacteria and methanogenic bacteria in a mixed culture of acclimated sludges, Water Res. 27 (1993) 1749-1759.

[34] J.O. Kim, Y.H. Kim, S.H. Yeom, B.K. Song, I.H. Kim, Enhancing continuous hydrogen gas production by the addition of nitrate into an anaerobic reactor, Process Biochem. 41 (2006) 1208-1212.

[35] W.L. Balderston, W.J. Payne, Inhibition of methanogenesis in salt marsh sediments and whole-cell suspensions of methanogenic bacteria by nitrogen oxides, Appl. Environ. Microbiol. 32 (1976) 264-269.

[36] G. Tchobanoglous, F.L. Burton, H.D. Stensel, Wastewater engineering: treatment and reuse, Metcalf \& Eddy, Inc., 4th ed., McGraw Hill, 2003

[37] J.C. Akunna, C. Bizeau, R. Moletta, Nitrate reduction by anaerobic sludge using glucose at various concentration: ammonification, denitrification and methanogenic activities, Environ. Technol. 15 (1994) 41-49.

[38] B. Calli, B. Mertoglu, B. Inanc, O. Yenigun, Effects of high free ammonia concentrations on the performances of anaerobic bioreactors, Process Biochem. 40 (2005) 1285-1292. 
Table 1

Ammonium concentration produced in the compartments

\begin{tabular}{ccc} 
Compartment & $\begin{array}{c}\text { Before adding } \\
\text { nitrate } \\
(\mathrm{mg} / \mathrm{L})\end{array}$ & $\begin{array}{c}\text { During } \\
\text { denitrification } \\
(\mathrm{mg} / \mathrm{L})\end{array}$ \\
\hline 1 & 117 & 345 \\
2 & 197 & 630 \\
3 & 276 & 777 \\
4 & 310 & 802 \\
5 & 342 & 812 \\
6 & 349 & 824 \\
\hline
\end{tabular}




\section{FIGURE CAPTIONS}

Figure 1. Schematic diagram of the experimental set-up used.

Figure 2. Profile of the (A) COD and (B) BOD concentration variations.

Figure 3. Profile of the (A) VFA and (B) $\mathrm{pH}$ variations.

Figure 4. Profile of the nitrate and nitrite concentration variations.

Figure 5. Effect of denitrification on the COD and BOD contents and VFA concentrations.

Figure 6. (A) The methane content in biogas; (B) the $\mathrm{CO}_{2}$ content in biogas; (C) the $\mathrm{N}_{2}$ content in biogas. 
Fig.1. Schematic diagram of the experimental set-up used

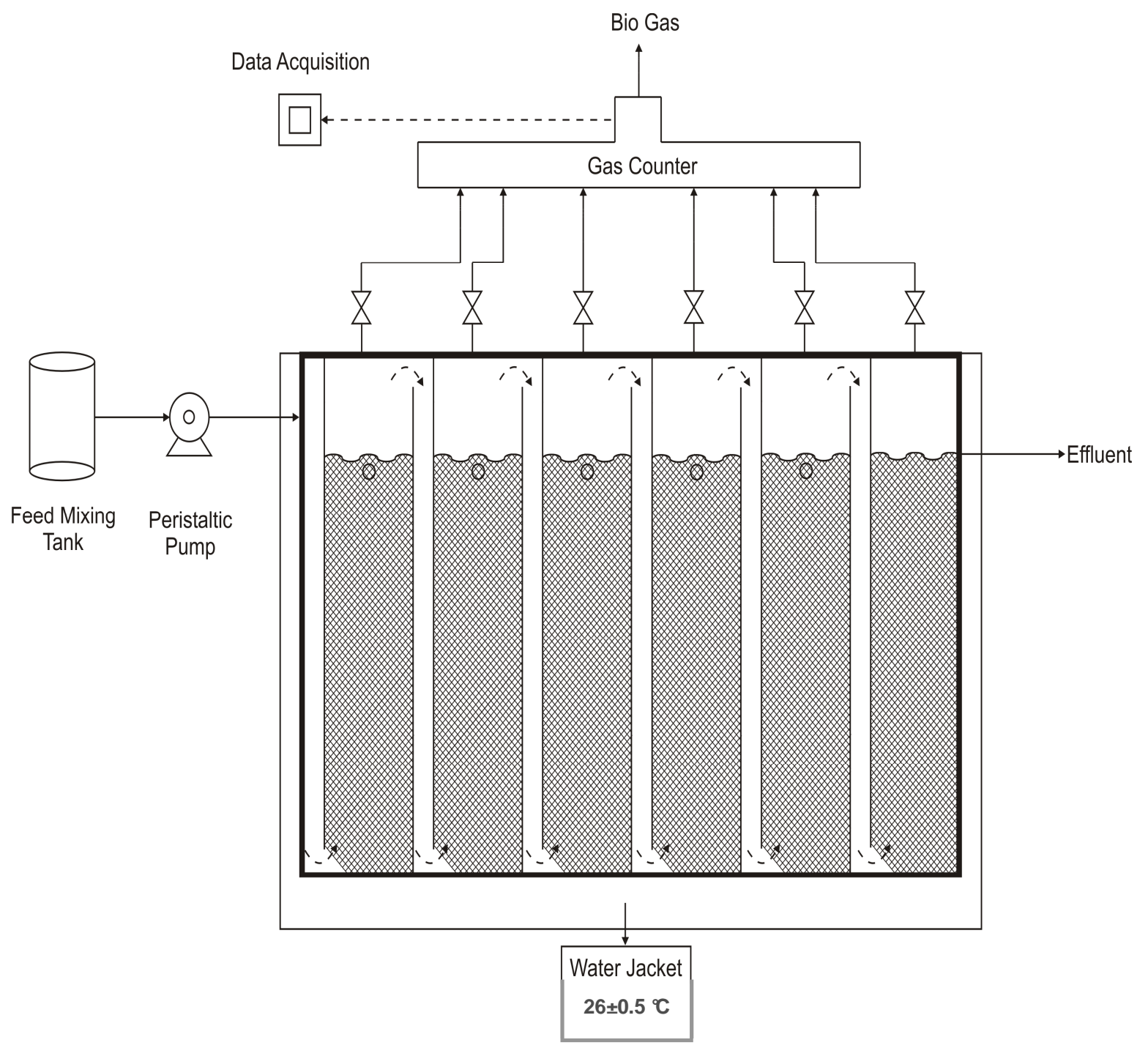



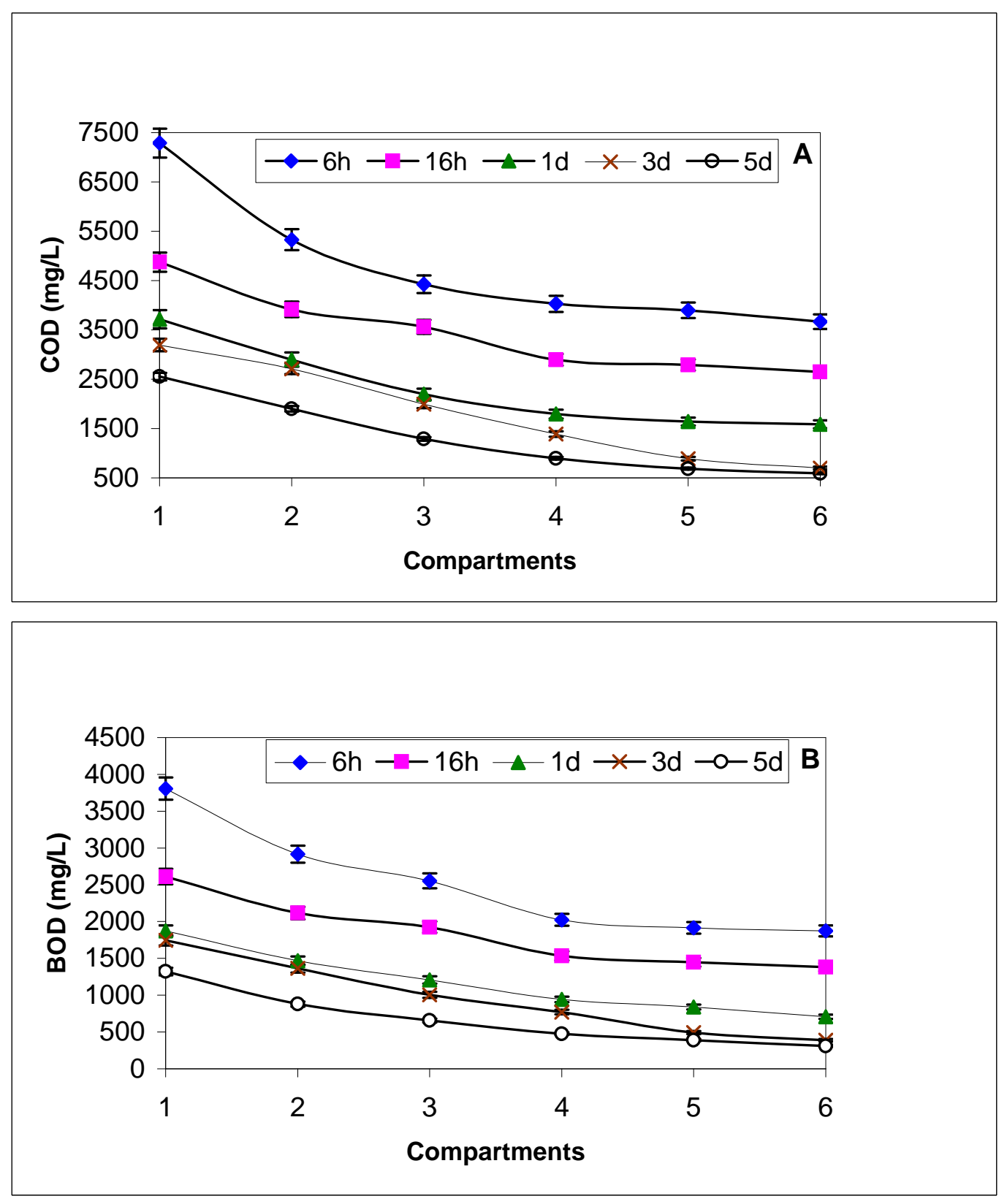

Fig. 2. Profile of the (A) COD and (B) BOD concentration variations. 

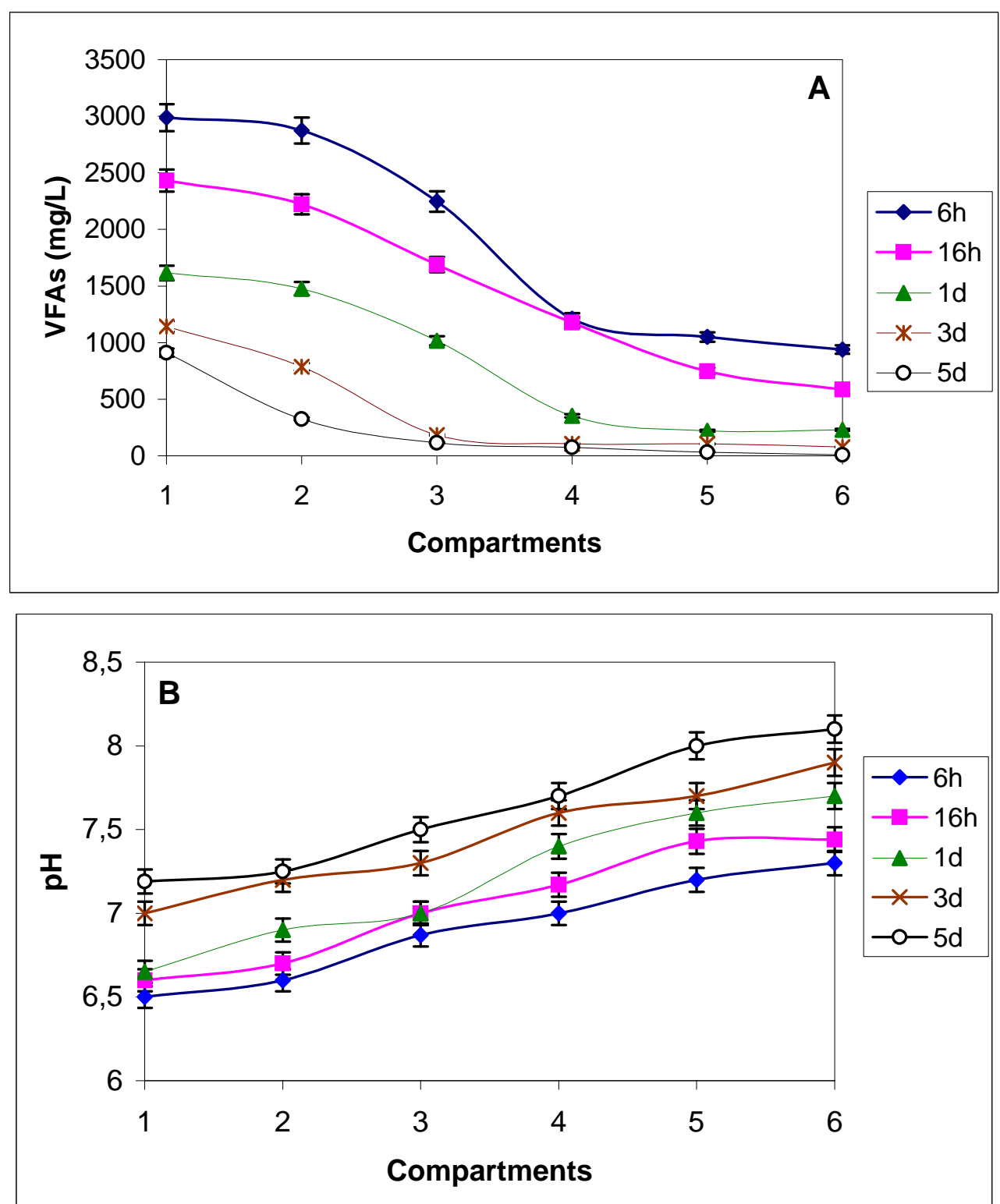

Fig. 3. Profile of the (A) VFA and (B) $\mathrm{pH}$ variations 


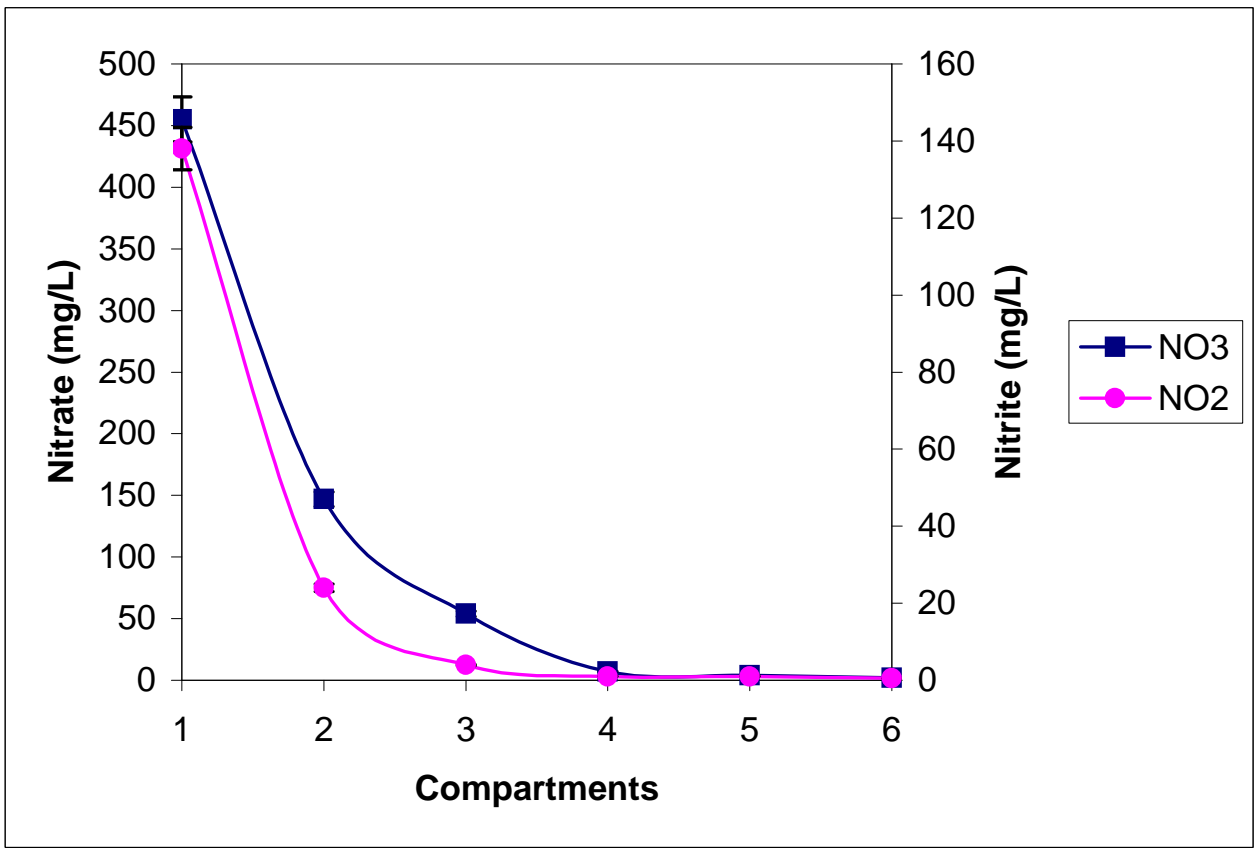

Fig. 4. Profile of the nitrate and nitrite concentration variations 


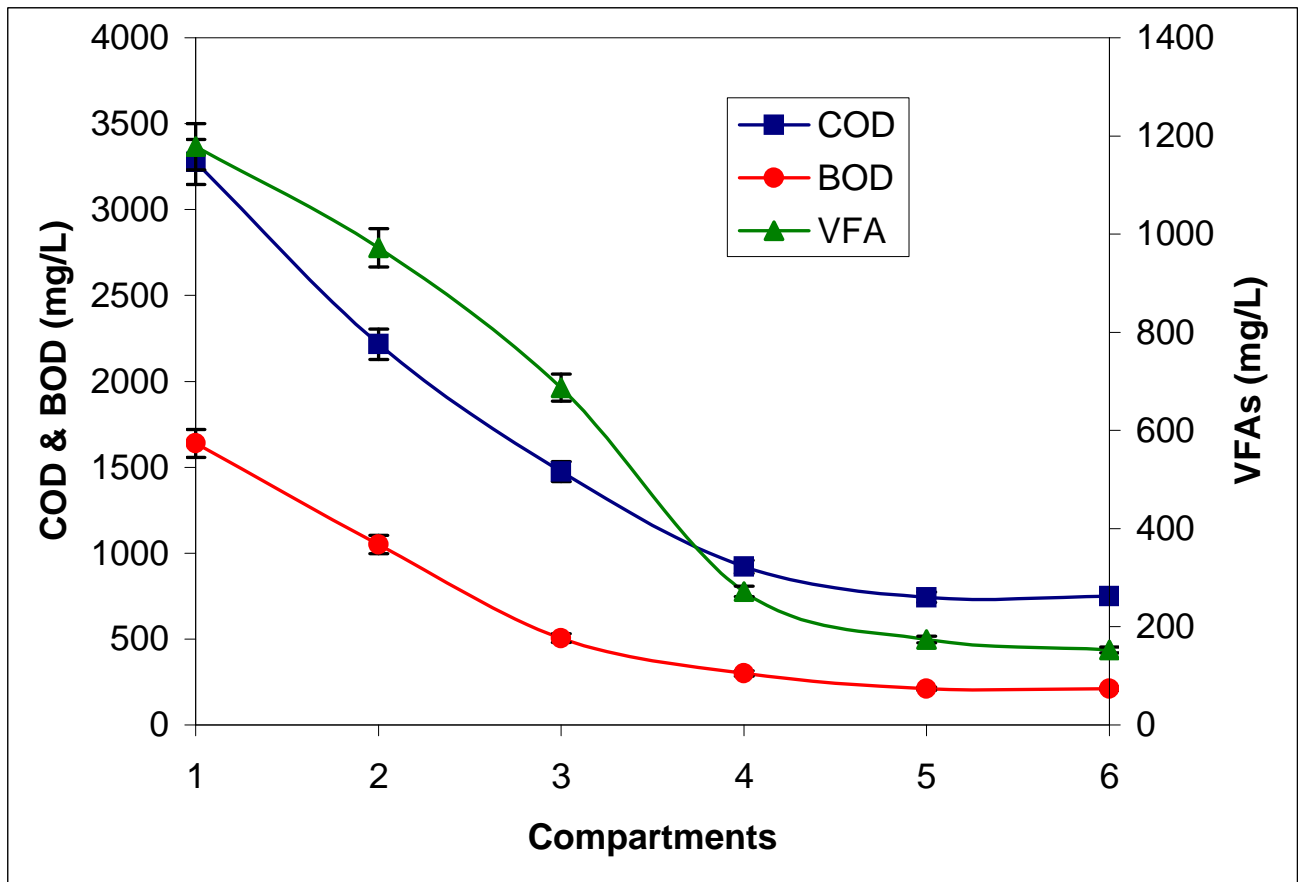

Fig. 5. Effect of denitrification on the COD and BOD contents and VFA concentrations 

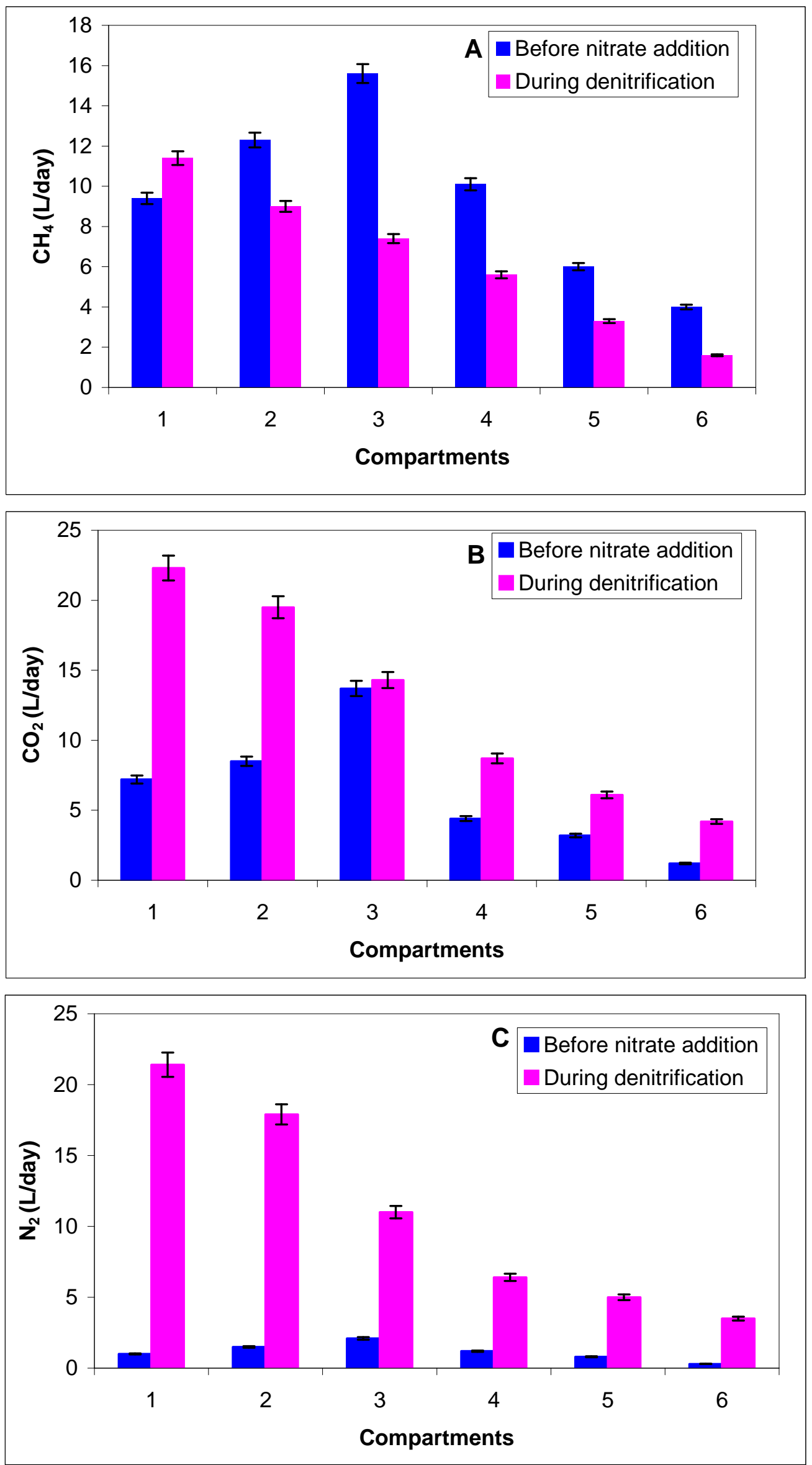
Fig.6. (A) The methane content in biogas; (B) the $\mathrm{CO}_{2}$ content in biogas; (C) the $\mathrm{N}_{2}$ content in biogas 